\title{
Expression of vimentin protein and neurofilament on forelimb buds of black-6 mice on gestation day 12 induced by 2 -methoxyethanol by RT- PCR
}

\author{
YULIA IRNIDAYANTI" \\ Department of Biology, Faculty of Mathematics and Natural Sciences, State University of Jakarta. Jl. Pemuda No. 10 Rawamangun, Jakarta Timur \\ 13220, Indonesia. Tel: +92-21-4894909. email: irnidayanti@ yahoo.com
}

Manuscript received: 31 Augustus 2010. Revision accepted: 16 October 2010

\begin{abstract}
Irnidayanti Y. 2010. Expression of vimentin protein and neurofilament on forelimb buds of black-6 mice on gestation day 12 induced by 2-methoxyethanol by Real-Time RT-PCR. Nusantara Bioscience 2: 116-120. The aim of this study was to investigate impact of 2-methoxyethanol, a major industrial chemical of plastic. Gene expression analysis is increasingly important in biological research, while real-time reverse transcription PCR (RT-PCR) is becoming the method of choice for high-throughput and accurate expression profiling of selected genes. Pregnant black-6 mice were injected intraperitoneally to $7.5 \mathrm{mmol} / \mathrm{kg}$ of 2 - methoxyethanol on gestation day (GD) 10. Embryo was obtained on gestation day 12. Forelimb buds of embryo were collected and then put in the tube, which containing RNA-latter solution. To identify gene expression changes in forelimb bud caused induction 2-methoxyethanol, Real-Time PCR was used in this research. For the experiments, the real-time RT-PCR Light Cycler technology was used. The results suggested that injection of 2methoxyethanol, in prenatal period especially on gestation day 12, the expression of vimentin in forelimb buds of mice treatment increase than control mice. Meanwhile, the expression of neurofilament tended to decrease, indirectly is not caused by the injection of 2methoxyethanol.
\end{abstract}

Keywords: vimentin, neurofilament, 2-methoxyethanol, limb bud, black-6 mice.

\begin{abstract}
Abstrak. Irnidayanti Y. 2010. Ekspresi protein vimetin dan neurofilamen pada tunas anggota depan mencit black-6 umur kebuntingan 12 hari akibat induksi 2-metoksietanol secara Real Time RT-PCR. Nusantara Bioscience 2: 116-120. Tujuan penelitian ini adalah untuk mengetahui dampak dari 2-metoksietanol, bahan kimia utama industri plastik. Analisis ekspresi gen semakin penting dalam penelitian biologi, dimana real-time reverse transcription PCR (RT-PCR) menjadi metode yang dipilih untuk mendapatkan profil ekspresi dari seleksi gen secara akurat. Mencit black-6 bunting diinjeksi 2-metoksietanol secara intraperitoneal dengan 7,5 mmol/kg pada umur kebuntingan 10 hari. Embrio diperoleh pada umur kebuntingan 12 hari. Tunas anggota depan embrio dikumpulkan dan dimasukkan ke dalam tabung, yang mengandung larutan RNA-latter. Untuk mengetahui perubahan ekspresi gen tunas anggota depan yang disebabkan oleh induksi 2-metoksietanol digunakan RT-PCR dalam penelitian ini. Dalam percobaan digunakan teknologi RT-PCR Light Cycler. Hasil penelitian menunjukkan bahwa injeksi 2- metoksietanol, pada periode pralahir terutama pada umur kebuntingan 12 hari, ekspresi vimentin pada tunas anggota depan mencit perlakuan meningkatkan dibandingkan kontrol. Sementara itu ekspresi neurofilamen cenderung menurun, secara tidak langsung tidak disebabkan oleh injeksi 2- metoksietanol.
\end{abstract}

Kata kunci: vimentin, neurofilamen, 2-metoksietanol, limb bud, mencit black-6.

\section{INTRODUCTION}

The compound of 2-methoxyethanol (2-ME) or ethylene glycol methyl ether is one of the glycol ether compounds derived from the compounds of phthalate esters. This compound is widely used as the basic material of plastic. Plastic is very useful in everyday life. People use plastics in their everyday life. Plastic is generally used for a variety of human activities, such as household appliances, packing materials, bottles, food containers, toys, water pipes and even used for the purposes of health such as blood storage for transfusion.

The waste of the compounds is often wasted in the environment and being the cause of pollutants, particularly in the aquatic environment or the river (Miller et al. 1983).
The compounds were known to be toxic or teratogenic in several mammalian species (Feuston et al. 1990). Some previous reports also mentioned that, some people have been poisoned with 2-ME through penetration into the skin and bronchial tube (Dugard et al. 1984). Approximately 100,000 people were poisoned by 2-ME per year, of which allegedly were women who were still in the fertile period or able to give birth (Scott et al. 1989). The teratogenic of 2-ME in experiment animal is caused by the metabolism of 2-ME in the hepatic cells transforming into methoxy acetic acid (MAA), by the help of a catalyst namely alcohol dehydrogenase (Brown et al. 1983; Moslen et al. 1995).

Our previous studies mentioned that, 2-ME causes abnormalities in fetal mice whose dams was given 2-ME or MAA, whose main disorders that appear were 
abnormalities the skeletons, the disorder on the axial skeleton, due to the damage of embryonic somit tissues which in turn led disorders on the spines and ribs, spina bifida; and exencephaly (Darmanto et al. 1994; Darmanto 1998). Some researchers have reported that after giving MAA with a single dose of $10 \mathrm{mmol} / \mathrm{kg}$ body weight on gestation day 11 of in mice JCL: ICR (Rasjad et al. 1991), AJ (Sudarwati 1993), Swiss Webster, (Suripto et al. 1996), showed that $94 \%$ of limb bud of the fetus experiment was abnormalities.

The nature of both Embryotoxic and teratogenic MAA compound has been shown in mammals, especially in embryos both pre and post-implantation periods. This embryotoxic characteristic is similar to that caused by the compound 2-ME (Darmanto et al. 1994).

Limb bud is a good model to study the pattern of certain growth and also to understand the possibility of developmental disorders caused by specific teratogens (Ruyani et al. 2008). The results of the research conducted by Rasjad et al. (1991), shows that the distribution pattern of defects caused by MAA, a metabolite of 2methoxyethanol, is caused by the difference in the number and distribution of dead cells that occurs in the mesoderm of the limb plate. The result of microscopic observations showed that signs of limb bud abnormality that experienced necrosis of mesenchymal cells and the AER (apical ectoderm Ridge), which was observed for 2 hours after being given MAA at gestation days to 10.5 , then after 6 hours showed hyperplasia on AER. AER itself plays a role in the formation mechanism of the disorder, because there is a degenerative change in structure and a more rapid depreciation in the fetus that was being treated compared than control (Sudarwati 1995). The results of the research by Mebus and Welsch (1989) that MAA treatment may interfere with the availability of purine and pyrimidine bases, which are expected to affect DNA and/or RNA synthesis, which in turn influence normal cellular proliferation and differentiation in the developing mouse embryos

In the process of formation of a normal limb bud, there are several phases: proliferation, migration, differentiation and cell death phase. When the embryo is gestation days 10 , it is an early stage of initial bud formation, in which cells undergo proliferation by forming AER.

In addition, there is also migration of myogenic cells on the buds. The muscular structure of the buds is partly from the myotome somites. The migration of myogenic cells begins soon after the formation of buds. The bud cells have the ability to aggregate forming two entities of muscles namely dorsal muscles and premuscular muscles, which are formed at the early stages of myogenic differentiation (Ewan and Everett 1997). Myogenic cells accumulated in the buds expressed vimentin proteins (Hayashi et al. 1993). The Results from Vaittinen et al. (2001), indicate that vimentin proteins play roles in myogenesis, both functional roles in the construction and restoration of skeletal muscle fibers. The presence of vimentin proteins related to cellular function of cells during embryonic development. So we can say that vimentin is expressed in the early phase of organogenesis, which is characterized by the aggregation and condensation of pre-cartilage (Viebahn et al. 1988). Vimentin role transports kinase into the cell nucleus. The kinase activates the neurons and affects gene expression in such a way that neurons can respond to the damage. This proves that vimentin is required in the repair of scar tissue through the migration of cells and tissue formation (Moon et al. 2004).

The expansion of those aggregated cells will stop when it reaches the form of condensation of pre-cartilages. The form of pre-cartilages condensation will trigger cartilage differentiation, which eventually forms cartilage (Lee et al. 1998). This development process includes the activities of cells namely cell migration, cell adhesion, intracellular signaling, and cell proliferation. The process of proliferation and migration of these myogenic cells are influenced by fibronectin. This protein helps facilitate the migration of myogenic cells, as a place of attachment and the guidance of the migration.

A neurofilament are a group of proteins that guide cells during the organogenesis process, if the expression level of these compounds is disturbed by the compound 2-ME, it is assumed that there will be abnormalities of limb bud. However, the abnormality that occurs is in the form of polydactyl, caused by dead cell, which is not the only mechanism that causes the appearance of disorder. Another research states that a failure in the functioning of the longitudinal and circular smooth muscle in cases of stenosis pyrolus, is known associated with the unexpressed ncam and neurofilament or indicating the absence of innervations on the smooth muscle tissues (Kobayashi et al. 1995). The development of the embryo limb buds would be disrupted, with a decrease of the expression neurofilament protein (Nicholas et al. 2004). Based on these results there might be any of a certain kind of disturbed protein expression that was induced by 2-ME compound. In this study, it is investigated the expressions of these proteins induced by 2-ME compound in the critical period of the development of the buds, in real-time RT-PCR. It is expected to know the proteins that are expressed during the formation of bud members and it is also expected to reveal the role of proteins in causing abnormalities limb buds.

\section{MATERIALS AND METHODS}

\section{Experimented animals}

Black-6 mice were used in this study were brought from Charite-Universutats Medizin Berlin. vaginal plug detected the following morning was defined as day 0 of gestation (Rugh 1968). The pregnant mice were killed by cervical dislocation at gestation days 10 (GD-10). The sample of the buds members was isolated under the microscope, and then put into the tube containing the RNA-latter, for the analysis of RNA and DNA. Test RNA was conducted with RNeasy Kits Real-Time RT-PCR.

\section{Materials, dosage and samples collection}

2-ME in liquid form (Product Number: 135-07762) was produced by Wako Pure Chemical Industries, Ltd. Japan. 2-ME diluted with sterilized distilled water was 
administered by peritoneally injection at a dose of 7.5 $\mathrm{mmol} / \mathrm{kg}$ body weight on GD-10. Control mice were given sterile distilled water with the same dose. On the GD-12, the mice were killed by cervical dislocation, and then the forelimb buds were isolated and put in tube with the latter RNA solution, then stored for further analysis at a temperature of $-20^{\circ} \mathrm{C}$.

\section{Real-Time RT-PCR}

The total RNA forelimb buds tissue was extracted with the RNeasy kit according to the manufacturer's protocols. cDNA was synthesized from the total RNA using the Qiagen One-Step RT-PCR Kit (Cat. No. 210 210). PCR reactions using enzymes AidTM $H$ Minus $M-M u L V R T$ (Cat. No. 130125486 ) at a temperature of $95^{\circ} \mathrm{C}, 7 \mathrm{~min}, 45$ cycles of PCR $\left(20 \mathrm{sec}, 95^{\circ} \mathrm{C}, 60^{\circ} \mathrm{C}, 20 \mathrm{sec}, 72^{\circ} \mathrm{C}, 30 \mathrm{sec}\right)$, $42^{\circ} \mathrm{C}$, during 1 hour 15 minutes, $70^{\circ} \mathrm{C}$ elongation then followed with the temperature of $70^{\circ} \mathrm{C}$, for 5 minutes. Quantitative analysis performed by Real-Time PCR. Analysis of Polymerase chain reaction (PCR) was done by adding each cDNA 9:00 $\mu$ l of treatment or control forelimb buds and $1 \mu \mathrm{l}$ of Primary-Mix into each different tube. In our experiments, Primary-Mix consists of 4 primary types of vimentin and NFh, Nfm, and NFl. In buds of both the control and treated, then was added by the component of reactions that was aqua, SYBER Green, $2 x$ Bioline buffer. Then reaction of Real-Time RT-PCR showed the complete series of targetted cDNA, followed by Oligonucleotide primers. The Primers used in this study were synthesized into Biotez Berlin-Buch GmbH (Berlin, Germany). Information on primers can be seen in Table 1 .

Table 1. Sequencing orimer position ( $\mathrm{f}=$ forward; $\mathrm{r}=$ reverse), $\%$ contens of $\mathrm{G} / \mathrm{C}$ dan referency primer product

\begin{tabular}{|c|c|c|c|}
\hline Primer & $\begin{array}{c}\text { Sequence } \\
\left(\mathbf{5}^{\prime} \square \square \square \square \square\left(3^{\prime}\right)\right.\end{array}$ & $\begin{array}{l}\text { GC } \\
(\%)\end{array}$ & TIB reference no. \\
\hline Vim-f & $\begin{array}{l}\text { CTG AGG CTG CCA } \\
\text { ACC GGA ACA A }\end{array}$ & 59,1 & 011701.3:1376F22 \\
\hline Vim-r & $\begin{array}{l}\text { CCT CGC CTT CCA } \\
\text { GCA GCT TCC }\end{array}$ & 66,7 & 011701.3:1682R21 \\
\hline Nef h-f & $\begin{array}{l}\text { AGG AGA TAA CTG } \\
\text { AGT ACC GGC G }\end{array}$ & 54,5 & 010904.3:1071F22 \\
\hline Nef h-r & $\begin{array}{l}\text { CCA AAG CCA ATC } \\
\text { CGA CAC TCT TC }\end{array}$ & 52,2 & 010904.3:1349R23 \\
\hline Nef m-f & $\begin{array}{l}\text { GTG GTT CAA ATG } \\
\text { CCG CTA CGC C }\end{array}$ & 59,1 & $008691.2: 1055 \mathrm{~F} 22$ \\
\hline Nef m-r & $\begin{array}{l}\text { GAG GCC CGG TGA } \\
\text { TGC TTC CTG }\end{array}$ & $66,, 7$ & 008691.2:1432R21 \\
\hline Nef 1-f & $\begin{array}{l}\text { TGG CCT TGG ACA } \\
\text { TCG AGA TTG CA }\end{array}$ & 52,2 & 010910:1221F23 \\
\hline Nef 1-r & $\begin{array}{l}\text { GCT TCT CCT TCA } \\
\text { GAG GGG GGC }\end{array}$ & 66,7 & 010910:1489R21 \\
\hline
\end{tabular}

Table 2. DNA cycle conditions forelimb buds proteins UK-12-day embryo induced by 2-ME in real-time reverse transcriptionpolymerase chain reaction (RT-PCR).

\begin{tabular}{|c|c|c|c|c|c|c|c|c|}
\hline No. & Name & $\mathrm{Ct}$ & $\begin{array}{l}\text { Take } \\
\text { Off }\end{array}$ & Amplification & $\begin{array}{l}\operatorname{Tm} \\
{\left[{ }^{\circ} \mathrm{C}\right]}\end{array}$ & $\underset{\left[{ }^{\circ} \mathrm{C}\right]}{\left.{ }^{\mathrm{C}}\right]}$ & $\begin{array}{l}\text { Calc. Conc. } \\
\text { (copies/reaction) }\end{array}$ & (copies/1Mio GAPDH) \\
\hline E1 & GAPDH - limbic E12 control & Sample & 13.04 & 14.1 & 1.73 & 86.1 & $3,017,422$ & \\
\hline E2 & $\mathrm{FN} 1 \mathrm{mix} 1$ & Sample & 23.14 & 24.5 & 1.76 & 86.1 & 38,135 & 12,638 \\
\hline E3 & FN1 mix2 & Sample & 25.45 & 27.1 & 1.70 & 86.6 & 14,033 & 4,651 \\
\hline E4 & FN1 mix3 & Sample & 27.99 & 29.5 & 1.80 & 86.6 & 4,675 & 1,549 \\
\hline E5 & Ncam1 & Sample & 24.95 & 26.2 & 1.79 & 87.1 & 17,423 & 5,774 \\
\hline E6 & Tnc & Sample & 24.48 & 26.0 & 1.77 & 84.9 & 21,354 & 7,077 \\
\hline E7 & Vim & Sample & 20.65 & 21.9 & 1.76 & 86.1 & 112,027 & 37,127 \\
\hline E8 & Nefh & Sample & 32.72 & 33.9 & 1.98 & 76.6 & 604 & 200 \\
\hline $\mathrm{F} 1$ & Nefm & Sample & 27.05 & 28.2 & 1.80 & 86.6 & 7,022 & 2,327 \\
\hline $\mathrm{F}_{2}$ & Nefl & Sample & 20.06 & 21.0 & 1.73 & 86.8 & 144,616 & 47,927 \\
\hline G1 & GAPDH - limbic E12 treated & Sample & 14.35 & 15.6 & 1.73 & 86.6 & $1,711,668$ & \\
\hline G2 & FN1 mix 1 & Sample & 20.55 & 22.0 & 1.75 & 86.1 & 116,982 & 68,344 \\
\hline G3 & FN1 mix2 & Sample & 22.32 & 23.9 & 1.72 & 86.6 & 54,381 & 31,771 \\
\hline G4 & FN1 mix 3 & Sample & 28.22 & 29.9 & 1.81 & 87.3 & 4,232 & 2,472 \\
\hline G5 & Ncam1 & Sample & 23.16 & 24.4 & 1.83 & 87.4 & 37,807 & 22,088 \\
\hline G6 & Tnc & Sample & 22.65 & 24.1 & 1.84 & 85.1 & 47,143 & 27,542 \\
\hline G7 & Vim & Sample & 17.35 & 18.7 & 1.80 & 86.4 & 467,267 & 272,989 \\
\hline G8 & Nefh & Sample & 30.69 & 32.3 & 1.74 & 77.8 & 1,453 & 849 \\
\hline $\mathrm{H} 1$ & Nefm & Sample & 25.13 & 26.8 & 1.83 & 89.1 & 16,118 & 9,416 \\
\hline $\mathrm{H}_{2}$ & Nefl & Sample & 21.89 & 23.3 & 1.77 & 86.6 & 65,504 & 38,269 \\
\hline
\end{tabular}


In Table 2, it is shown that the number of copies of genes for vimentin expression is very high compared with vimentin protein gene in the control group. The number of the copies of genes is around 272,989, relatively higher compared than control that is 37,127 . While the number of the copies of neurofilament low protein in the treatment group was lower than the control group, that is 38,269 for the group of treatment and 47,927 for that of control. While the medium and high neurofilament is very low in the treatment group that is 9416 and 849, while in the control are 2327 and 200.

\section{RESULTS AND DISCUSSION}

Results of DNA copies by the real-time $R T-P C R$ is from the mice black -6 using the primers of vimentin and high, medium and low neurofilament low (figure 1). In the picture above, it is shown that the expression of vimentin in the early development of limb buds is very high. Other proteins such as $n f$-low look the opposite that is relatively decreased, when compared with the control group.

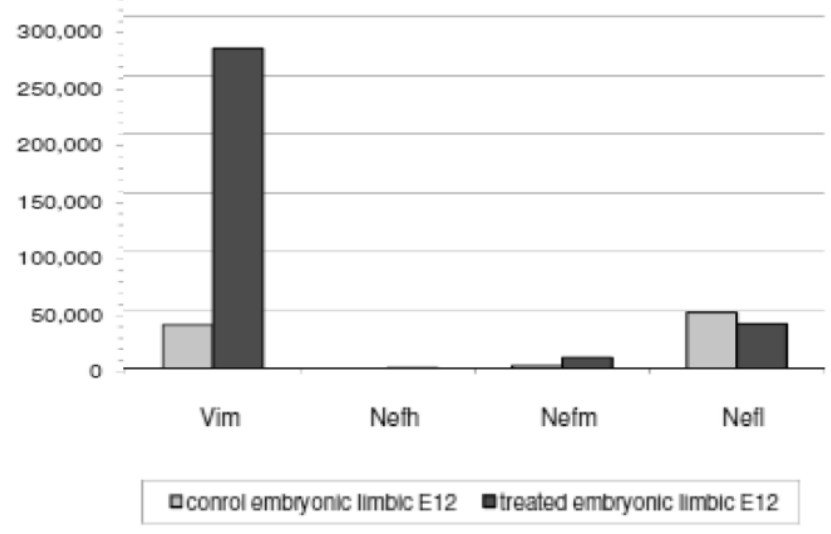

Figure 1. The number of copies of genes for DNA protein embryonic forelimb buds on GD-12, the results of real-time RTPCR between forelimb buds of the control and treated with 2ME.

\section{Discussion}

The limb buds firstly appear on the $10^{\text {th }}$ day of gestation, which seems a group of mesenchyme cells that grow like forelimb bud. Mesenchyme cells that cover the primordium limb buds will form the cube-shaped cells derived from ectoderm layer. This form is known as the apical ectoderm Ridge (AER). On the $12^{\text {th }}$ gestation day, the limb buds turn themselves in the shape of polygonal or rather pentagonal. The role of proteins in the development of limb buds, can directly work on the cells or through an intermediary by changing the configuration of the substrate. In the process of formation of a normal limb bud, there are several phases: proliferation, migration, differentiation and cell death phase. In embryo on the $10^{\text {th }}$ days gestation, is the early stage of limb buds formation, in which cells undergo proliferation by forming AER. In addition, there is also a migration of myogenic cells in the limb buds. Myogenic cells accumulated in the limb buds, express vimentin proteins (Hayashi et al. 1993).

From the results of this study, it is shown that vimentin protein expression in treatment group increased compared to the control one. Under normal circumstances, the expression of vimentin protein in embryonic period on GD10 is very high (Irnidayanti 2009), then gets decreased on the GD-12. But in this study, after injected with 2-ME, the expression of vimentin protein appears the opposite, that it gets increased on GD-12. These data are supported by Vaittinen et al. (2001), that the expression of vimentin increases maximum for 3-5 days after the post-injury on the myoblast. This means that after being given with $2-\mathrm{ME}$, there occurs damage on limb buds tissue. In the damaged tissue, it can be seen the raising of the expression of vimentin protein. The high expression of vimentin protein is needed to repair the damaged tissue induced by 2-ME.

Based on the research by (Viebahn et al. 1988) showed that the existence of protein expression appears to be associated with cellular functions during embryonic development. Vimentin, which is an intermediate filament, acts as transduction signal (Helfand et al. 2005). Vimentin can interact with the MAP (mitogen-activated protein) kinase, which is found on the tip of the injured axon. Vimentin plays role in transporting the kinase into the body and toward nucleus of cells. The Kinase activates and affects the expression of the neuron gene in such a way that the neurons can respond to the damage. Moon et al. (2004) stated that vimentin is a lot of expressed in damaged tissue. Therefore it is suggested that the high expression of vimentin protein in embryo on GD-12 is related with the process of proliferation and migration of cells needed for repairing the limb buds tissue, as a result of being given with 2-ME. In this study, the giving of 2-ME was done on the $10^{\text {th }}$ days gestation and the observations were made on the $12^{\text {th }} .48$ hours after being given with the 2-ME, which is not the end of the recovery effort, it leads to a very high expression of vimentin and it is indispensable to the process of proliferation in repairing the tissues. The results of the Ruyani's research (2008) states that after giving 2$\mathrm{ME}$ in Swiss Webster mice on the $10^{\text {th }}$ day with a dose of $10 \mathrm{mmol} / \mathrm{kg}$ body weight, the protein profile of the forelimb buds changed. The metabolite result of 2-ME, the MAA, directly effects on gene expression which then also affects the existence of certain proteins. Thus the high expression of vimentin protein is required for tissue repairing due to being given with 2-ME and are associated with functions of the cells during the development stage

The expression of Neurofilament-low protein in the treatment group, seemed lower compared to that in the control group. The expression of the three sub-units of neurofilament varied, both among the population of neurons and the axons in the development stage. The expressions of the three subunits are associated with various functions of the cells during the development stage (Viebahn 1988). As it is already known that, neurofilament plays role in the morphogenesis process of the neurons (Matus 1988; Robinson and Anderton 1988; Riederer 1991; Riederer, 1992), mainly to maintain the rigidity of the cell. 
Besides that it also serves to guide the intracellular transport into the axons and dendrites. Together with other cytoskeleton proteins, neurofilament functions role in establishing and maintaining the cells' shape and in facilitating the transportation of particles and organelles within cytoplasm (Liu et al. 2004). Given the nerve supply and muscle into the limb buds began to occur in the embryo on the $13^{\text {th }}$ day gestation, the expression of neurofilament-low protein also appears lower in the control group. From the data obtained, it is shown that the expression of neurofilament-low protein got decreased after being given with $2-\mathrm{ME}$ on the $10^{\text {th }}$ day of pregnancy, that was apparently not caused by disruption of RNA and DNA synthesis by $2-\mathrm{ME}$. The low expression neurofilamen-low protein was not caused by the compound 2-ME, considering the fact that the innervation of nerves occurred on the $13^{\text {th }}$ day of pregnancy. While neurofilament medium and neurofilament-high protein began to appear expressed, which tended to increase compared to that of the control group.

\section{CONCLUSION}

A single dose of 2-methoxyethanol $7.5 \mathrm{mmol} / \mathrm{kg}$ body weight given intraperitoneally on gestation day 10 , causes an increase in vimentin protein expression. And the decrease expression in neurofilament protein in the forelimb buds of mice embryo is not caused by 2 methoxyethanol.

\section{ACKNOWLEDGEMENTS}

This research was funded by the Sandwich Like Program of the Directorate General of Higher Education, 2008. To that end, the authors thank.

\section{REFERENCES}

Brown ZW, Amit Z, Smith BR, Sutherland EA, Selvaggi N. 1983. Alcohol-induced euphoria enhanced by disulfiram and calcium carbimide. Alcohol Clin Exp Res 7:276 \pm 8 .

Darmanto W. 1998. Effect of 2-methoxyethanol to somite formation and axial bone abnormalities in mice. Proceeding of $7^{\text {th }}$ Scientific Meeting, Hiroshima, Japan.

Darmanto W, Sudarwati S, Sutasurya LA. 1994. Effects of methoxy acetic acid on prenatal development of mice. Environ Med 38: 25-28.

Dugard PH, Walker M, Mawdsley SJ, Scott RC. 1984. Absorption of some glycol ethers through human skin in vitro. Environ Health Perspect 57: 193-197.

Ewan KBR, Everett AW. 1997. Migration of myogenic cells in the developing limb. Basic Appl Myol 7 (2): 131-135.

Feuston MH, Kerstetter SL, Wilson PD. 1990. Teratogenicity of 2 methoxyethanol applied as a single dermal dose to rats. Fundam Appl Toxicol 15: 448-456.

Hayashi K, Hagiwara Y, Ozawa E. 1993. Vimentin expression pattern is different between the flank region and limb regions of somatopleural mesoderm in the chicken embryo. Develop Growth Differ 35: $301-$ 309.

Helfand BT, Chou YH, Shumaker DK, Goldman RD. 2005. Intermediate filament proteins participate in signal transduction. Trends Cell Biol 15 (11): 568-570.
Irnidayanti Y. 2009. Comparison of the expression of cDNA extra cellular matrix protein between brain E-10 days black- 6 mice, hLN-405, rF98 and cell line mHT-22. Research Sandwich Program, Humboldt University, Berlin.

Kobayashi H, O'Brien DS, Puri P. 1995. Immunochemical characterization of neural cell adhesion molecule (NCAM), nitric oxide syntethase, and neurofilament protein expression in pyrrolic muscle of patients with pyrrolic stenosis. J Pediatr Gastroenterol Nutr 20 (3): 319-325

Lee YS, Stott NS, Jiang RB, Widelitz, Chuong CM. 1998. Early events during precartilago condensation in limb bud micromass culture. Cells Mater 8: 19-32.

Liu Q, Xieb F, Siedlak SL, Nunomurac A, Hondaa K, Moreiraa PI, Zhua X, Smitha MA, Perrya G. 2004. Neurofilament proteins in neurodegenerative diseases. Rev Cell Mol Life Sci 61: 3057-3075.

Matus A. 1988. Microtubule-associated proteins: Their potential role in determining neuronal morphology. Annu Rev Neurosci 11:29-44.

Mebus CA, Welsch F, 1989. The possible role of one-carbon moieties in 2-methoxyethanol and 2-methoxy acetic acid induced development toxicity. Toxicol Appl Pharmaco 99: 98-109.

Miller RR, Hermann EA, Langvardt PW, McKenna J, Schwetz, BA. 1983. Comparative Metabolism and Disposition of Ethylene Glycol Monomethyl Ether and Propylene Glycol Monomethyl Ether in Male Rats. Toxic App Pharmac 67: 229-237.

Moon C, Ahn M, Kim S, Jin JK, Sim KB, Kim HM, Lee MY, Shin T. 2004. Temporal patterns of the embryonic intermediate filaments nestin and vimentin expression in the cerebral cortex of adult rats after cryoinjury. Brain Res 1028: 238-242

Moslen MT, Kaphalia L, Balasubramanian H, Yin YM, William WA. 1995. Species differences in testicular and hepatic biotransformation of 2-methoxyethanol. Toxicol 96: 217-224.

Nicholas MA, Cai L, Brown DD. 2004. Thyroid hormone controls the developments between the spinal cord and limbs during Xenopus laevis metamorphosis. Proc Nat Acad Sci USA 101 (1): 165-170.

Rasjad C, Yamashita K, Datu AR Yasuda M. 1991. Pathogenesis of limb malformation in mice induced by methoxyacetic acid. Hiroshima $\mathbf{J}$ Med Sci 40(3):101-107.

Riederer BM. 1992. Differential phosphorylation of some proteins of the neuronal cytoskeleton during brain development. Histochem J 24: 783-790.

Riederer BM, Innocenti GM. 1991. Differential distribution of tau proteins in developing cat cerebral cortex and corpus callosum. Eur J Neurosci 3(11): 1134-1145.

Robinson PA, Anderton BH. 1988. Neurofilament probes-a review of neurofilament distribution and biology. Rev Neurosci 2: 1-40.

Rugh R. 1968. The mouse: its reproduction and development. Burgess, Minneapolis.

Ruyani A, Sudarwati S, Sutasurya LS, Sumarsono SH. 2008. Changes in protein profile of the front limb buds of mice (Mus musculus) Swiss Webster treated with methoxyacetic acid (MAA). Bandung Institute of Technology, Bandung. [Indonesian]

Scott WJ, Fradkin R, Wittfoht W, Nau H. 1989. Teratologic potential of 2metoxyethanol and transplacental distribution of its metabolite, 2methoxyacetic acid, in non-human primates. Teratology 39: 363-373.

Sudarwati S, Surjono TW, Yusuf AT. 1993. Effect "methoxyacetic acid" (MAA) to the development of mice extremity (Mus musculus) strains A/J. J Matematika \& Sains 1: 11-19. [Indonesian]

Sudarwati S, Surjono TW, Yusuf AT. 1995. Abnormalities of the early development of the front extremity of mice A/J strain induced by methoxyacetic acid (MAA). J Matematika \& Sains, Suplement H: 6070. [Indonesian]

Suripto S, Surjono TW, Kamal A. 1996. Influence of methoxyacetic acid on DNA content of embryonic limb mice (Mus musculus) Swiss Webster. [Research Report]. Bandung Institute of Technology, Bandung. [Indonesian]

Vaittinen S. Lukka R, Sahlgren C, Hurme T, Rantanen J, Lendahl U, Eriksson JE, Kalimo H. 2001. The expression of intermediate filament protein nestin as related to vimentin and desmin in regenerating skeletal muscle. J Neuropathol Experiment Neurol 60 (6): 588-597.

Viebahn C, Lane EB, Ramaekers FCS. 1988. Keratin and vimentin in early organogenesis of the rabbit embryo. Cell Tissue Res 253: 553-562. 